\title{
The Effect of Classes through Google Classroom due to COVID-19 on Outcome-Based Nursing Education
}

\author{
Me-Ok Yoon ${ }^{1}$, Suk-Young Lee ${ }^{2}$, and Seong-Sup Suk ${ }^{3}$ \\ ${ }^{1}$ Dept. of Nursing, Hanil University \& Presbyterian Theological Seminary, 726-15 \\ Sangwon-myeon, Wanju-gun, Jeollabuk-dol, 55359, Korea \\ 1yoonhospice@hanil.ac.kr, ${ }^{2}$ sarah@hanil.ac.kr, ${ }^{3}$ so@hanil.ac.kr
}

\begin{abstract}
This study was conducted to develop and evaluate the impact of education through Google Classroom on outcome-based nursing education such as critical thinking, problem-solving ability, self-regulated learning ability, and academic major satisfaction with the face-to-face instructional closure due to COVID-19. The methodology used in this research is an quasiexperimental study of a group of pretest-posttest design, which was designed to check for differences before and after the intervention through Google Classroom to the treatment group. For a total of six weeks from March 16, 2020, to April 24, 2020, H University, located in $J$ city, has taught eight nursing courses in the first, second, third, and fourth grades through Google Classroom. The collected data were analyzed with descriptive statistics and paired t-test using the SPSS WIN 23.0 program. The effects of education with Google Classroom on critical thinking ability, problem-solving ability, self-regulated ability and academic major satisfaction were statistically significant as follows: critical thinking ability $(t=-3.48 p=) .000)$, self-regulating learning ability $(t=-3.35, p=.001)$, problem-solving ability $(t=-3.49, p=.001)$, and academic major satisfaction $(t=-2.81, p=.016)$. The above findings confirmed that applying Google Classroom to nursing education can have a positive impact on critical thinking, problem-solving ability, and self-regulated learning ability among nursing students, and increase academic major satisfaction.
\end{abstract}

Keywords: Google classroom, COVID-19, Critical thinking, Problem-solving ability, Selfregulated learning ability, Academic major satisfaction

\section{Introduction}

\subsection{Need for research}

Because of the COVID-19 in WHO, on March 11, 2020, the pandemics Declaration was made. A new type of COVID-19 pandemics has been issued worldwide to prevent mass infection [1]. School closures can be mainly divided into reactive closures, which are closed when an infected person is found in a school, and proactive closures, which are taken before an infected person is found in a school. School closures reduce the cumulative infection rate by about 25 percent and delay the peak of the epidemic by two weeks [2][3]. Elementary, middle, and high schools in Korea also postpone the face-to-face opening of schools and offer

*This paper is from 3rd Domestic and International Integration Conference, June, 2020

Article history:

Received (May 17, 2020), Review Result (June 21, 2020), Accepted (July 26, 2020) 
online classes as an alternative. School closures play an important role in preventing the spread of COVID-19 to students. Although the classroom situation of face-to-face classes cannot be realized $100 \%$, attempts should be made to convey knowledge through Internet lectures in order to realize the school classes that require meetings with students even if students cannot come to school. In the midst of difficulties caused by the threat of Corona Virus, for future education, an attempt is needed to look at the direction of education differently from the perspective that the current crisis can be an opportunity.

In response, this study conducted eight nursing courses through Google Classroom to examine the impact on the nursing learning achievement of critical thinking ability, problemsolving ability, self-regulated learning ability, and academic major satisfaction.

\subsection{Purpose of research}

The purpose of this study is to investigate the impact of education through Google Classroom on critical thinking, problem-solving, self-regulated learning, and academic major satisfaction of nursing school students, as follows:

After classes through Google Classroom, to review the status of critical thinking, interpersonal relationship, self-leadership, academic major satisfaction.

After classes through Google Classroom, to review the difference in critical thinking ability.

After classes through Google Classroom to review the difference in problem-solving skills.

After classes through Google Classroom, to review the difference in self-control learning ability.

After classes through Google Classroom, to review the difference in class satisfaction level.

After classes through Google Classroom, to review the correlation between critical thinking ability, problem-solving ability, self-regulated learning ability, and academic major satisfaction.

\section{Research method}

\subsection{Research design}

This study is a quasi-experiment study of a group of pretest-posttest designs to identify the effects of nursing subjects on critical thinking ability, problem-solving ability, self-regulated learning ability, and academic major satisfaction by education through Google Classroom.

\subsection{Object of study}

The subjects of this study were students in grades 1 to 4 of the Department of Nursing at $\mathrm{H}$ University located in Jeollabuk-do Province, where nursing classes were conducted through the Google Classroom as an alternative to face-to-face instruction due to school closures due to the new COVID-19 pandemic. 100 students understood the purpose of the study and agreed to participate voluntarily. Of those, 96 copies, not 100, were used as final statistical analysis data. G-power 3.1.2, using the program, the minimum sample size required for t-test was obtained, and 9 samples in this study were appropriate based on a significant level of .05, power of.80 and effect size of .5.

\subsection{Progress of teaching by Google classroom}


The most effective platform for feedback in the curriculum is the Google Classroom. For a total of 6 weeks from March 16, 2020 to April 25, 2020, classes based on Google Classroom operated 8 nursing courses, including maternal nursing, mental nursing, basic nursing, spiritual nursing, and critical care nursing. Three professors prepared lecture materials for their subjects and gave lectures in the Google Classroom. The class proceeded as follows.

Step 1: Before proceeding with the Google Classroom, we explained the purpose, method, and evaluation process of the class and opened a Google Classroom for the subject.

Step 2: The contents of the online classes of the Google Classroom were set up to be uploaded at the relevant date and time so that professors could shoot and record lectures directly through videos they meet in the Google Classroom. Students were then able to access and participate in the class at that time.

Strp 3: Students turn on Chromebook in their rooms and enter the Google Classroom during classes where videos and assignments reserved by the professor are uploaded. Students watch videos and read instructions from professors. Then, when students select the attached document, a Google document created by the professor opens. Classes end when students solve, record, and submit questions in the form of a narrative. Upon receiving the assignment, the professor gave feedback to the students' writings in the form of narrative or correction. Students were notified immediately upon returning the problematic task or completing the grading.

\subsection{Research tool}

\subsubsection{Critical thinking}

In this study, "critical thinking" refers to personal propensity and cognitive impetus toward independent decision-making, with motivation for personal or professional work [4]. To measure critical thinking patterns, a critical thinking attitude measurement tool developed by Yoon Jin was used [5]. The tool comprises five questions of intellectual passion/attention, four questions of prudence, four questions of confidence, three questions of systematicness, four questions of intellectual fairness, four questions of sound skepticism, and three questions of objectiveness, adding up to 27 questions and seven factors in total. Formulated into a questionnaire, this consists of 5 Likert measures from "not at all" (1 point) to "very yes" (5 points). : the higher the score, the higher the likelihood of critical thinking. The reliability of the tool at the time of development was Cronbach's Alpha .94. The reliability of this study is Cronbach's Alpha 74.

\subsubsection{Self-regulated learning ability}

The self-regulating learning ability was accomplished by revising the self-regulating learning questions of Pintrich to suit the study [6]. A total of 15 questionnaires are asked mainly about learning methods and learning attitudes, and the response form consists of a Likert 5 points scale from "very not" to "very much." The reliability of the tool at the time of development was Cronbach's Alpha .84. The reliability of this study is Cronbach's Alpha .64.

\subsubsection{Problem-solving ability}

Among the life ability measurement tools developed by the Korea Educational Development Institute [7], problem-solving skills measurement tools for college students and adults were used to measure problem-solving skills. The tool consists of 45 questions in nine 
sub-sections, such as problem recognition (5 questions), information collection (5 questions), analytical skills (5 questions), widespread thinking (5 questions), decision (5 questions), planning (5 questions), execution and adventure taking (5 questions), assessment (5 questions), and feedback (5 questions). This tool is very rare on a 5-point Likert scale. Very often from 1 point to 5 points. The higher the score, the higher the score, the higher the problem-solving ability. The reliability of the tool at the time of development was Cronbach's Alpha .72. The reliability of this study is Cronbach's Alpha .64.

\subsubsection{Academic major satisfaction}

Academic major satisfaction is the product of the judging process that evaluates the major to which one is currently affiliated [8] compared to the criteria for career or career established by an individual. In this study, the scores were measured using the Majority Satisfaction Tool developed by Kim \& Ha [9], comprising a total of 16 questions. It must be responded to on a 5 -point Likert scale, from 1 point "not altogether" to 5 points "very much," meaning that the higher the score, the higher the academic major satisfaction. The reliability of the tool at the time of development was Cronbach's Alpha .86. The reliability of this study is Cronbach's Alpha .72.

\subsection{Data analysis}

The collected data were analyzed using SPSS version WIN 23.0. The specific analysis method obtained the average, standard deviation, frequency and percentage of the subject's general characteristics, critical thinking, problem-solving ability, self-regulated learning ability, and academic major satisfaction level, and analyzed the difference between critical thinking, problem-solving ability, self-control learning ability, and class satisfaction before and after classes through the Google Classroom as a pair-test. Cronbach's $\alpha$ lpa was calculated to measure the reliability of the measuring tool.

\section{Results of the study}

\subsection{General characteristics}

In general, the number of female students was 63 (65.2\%), the sample age was 21-24 years old with $81(84.8 \%)$.

Table 1. General characteristics $(\mathrm{N}=96)$

\begin{tabular}{|c|c|c|}
\hline \multicolumn{2}{|c|}{ Characteristics } & $\mathrm{n}(\%)$ or M( $\pm \mathrm{SD})$ \\
\hline \multirow{2}{*}{ Sex } & $\mathrm{M}$ & $33(34.8 \%)$ \\
\cline { 2 - 3 } & $\mathrm{F}$ & $63(65.2 \%)$ \\
\hline \multirow{3}{*}{ age } & 20 or less & $9(0.9 \%)$ \\
\cline { 2 - 3 } & $21-24$ & $81(84.8 \%)$ \\
\cline { 2 - 3 } & over 25 & $6(0.6 \%)$ \\
\hline
\end{tabular}

3.2. Differences in critical thinking, self-regulated learning ability, problem-solving ability, and academic major satisfaction after applying teaching method through google classroom 
After playing Google Classroom, the average score of critical thinking ability increased by 5.23 points from $89.02 \pm 5.37$ before the intervention to $94.25 \pm 11.11$ after the intervention( $t$ $=,-3.48 \mathrm{p}=.000$ ). That of Self-Regulated Learning Ability increased by 4.1 points from an average of $50.45 \pm 15.16$ before the intervention to $54.56 \pm 20.81$ after the intervention( $\mathrm{t}=-3.35$, $\mathrm{p}=.001$ ); Problem-Solving Ability increased 4.5 points from $152.21 \pm 23.14$ before the intervention to $156.91 \pm 21.98$ after the intervention $(\mathrm{t}=-3.49, \mathrm{p}=.001)$; major satisfaction increased by 3.8 points from $57.56 \pm 9.03$ before the intervention to $61.37 \pm 7.98$ after the intervention, and the difference was significant $(\mathrm{t}=-2.81, \mathrm{p}=.016)$. The six-week Google Classroom class, conducted as a non-face-to-face lecture due to Covid-19 in performancebased nursing education, was shown to improve the critical thinking, problem-solving skills, self-regulation ability and major satisfaction of nursing students. The results after classes through the Google Classroom are as shown in the table below [Table 2].

Table 2. Differences in critical thinking, self-regulated learning ability, problem-solving ability, and academic major satisfaction after applying teaching method through google classroom $(\mathrm{N}=96)$

\begin{tabular}{|c|c|c|c|c|c|}
\hline Variables & $\begin{array}{l}\text { Pretest } \\
\mathrm{M} \pm \mathrm{SD}\end{array}$ & $\begin{array}{l}\text { Posttest } \\
\mathrm{M} \pm \mathrm{SD}\end{array}$ & $\begin{array}{l}\text { Paired Differences } \\
\qquad \mathrm{M} \pm \mathrm{SD}\end{array}$ & $\mathrm{t}$ & $\mathrm{p}$ \\
\hline Critical thinking & $89.02 \pm 5.37$ & $94.25 \pm 11.11$ & $-5.23 \pm 15.05$ & -3.48 & $.000 * * *$ \\
\hline $\begin{array}{l}\text { Self-Regulated Learning } \\
\text { Ability }\end{array}$ & $50.45 \pm 15.16$ & $54.56 \pm 20.81$ & $-4.11 \pm 5.65$ & -3.35 & $.001 * * *$ \\
\hline Problem-Solving Ability & $152.21 \pm 23.14$ & $156.91 \pm 21.98$ & $-4.52 \pm 10.54$ & -3.49 & $.001 * * *$ \\
\hline $\begin{array}{c}\text { Academic Major } \\
\text { Satisfaction }\end{array}$ & $57.56 \pm 9.03$ & $61.37 \pm 7.98$ & $-3.81 \pm 10.96$ & -2.81 & $.016^{* *}$ \\
\hline
\end{tabular}

\subsection{Difference of critical thinking after applying teaching method through google classroom}

After Google Classroom, objectivity $(\mathrm{t}=-2.56, \mathrm{p}=.014)$, healthy skepticism $(\mathrm{t}=-2.17, \mathrm{p}=.035)$ and Intellectual eagerness/Curiosity $(\mathrm{t}=-3.29, \mathrm{p}=.002)$ showed significant differences. There were no differences in Intellectual fairness $(\mathrm{t}=.899, \mathrm{p}=.478)$, prudence $(\mathrm{t}=-.51, \mathrm{p}=.656)$, and Systematicity $(\mathrm{t}=-.12, \mathrm{p}=.905)$ [Table 3$]$.

Table 3. Difference of critical thinking after applying teaching method through google classroom $(\mathrm{N}=96)$

\begin{tabular}{|c|c|c|c|c|c|}
\hline Variables & $\begin{array}{l}\text { Pretest } \\
\mathrm{M} \pm \mathrm{SD}\end{array}$ & $\begin{array}{l}\text { Posttest } \\
\mathrm{M} \pm \mathrm{SD}\end{array}$ & $\begin{array}{l}\text { Paired Differences } \\
\qquad \pm \pm S D\end{array}$ & $\mathrm{t}$ & $\mathrm{p}$ \\
\hline Intellectual fairness & $8.02 \pm 1.06$ & $7.98 \pm 1.03$ & $.04 \pm 1.53$ & .899 & .478 \\
\hline prudence & $11.61 \pm 1.39$ & $11.73 \pm 1.51$ & $-.12 \pm 2.10$ & -.51 & .656 \\
\hline Objectivity & $13.15 \pm 1.68$ & $13.96 \pm 1.89$ & $-.82 \pm 2.60$ & -.2 .56 & $.014 * *$ \\
\hline healthy skepticism & $13.80 \pm 2.26$ & $14.75 \pm 2.37$ & $-.84 \pm 3.18$ & -2.17 & $.035 * *$ \\
\hline Systematicity & $6.86 \pm 1.45$ & $6.89 \pm 1.57$ & $-.03 \pm 2.05$ & -.12 & .905 \\
\hline $\begin{array}{c}\text { Intellectual } \\
\text { eagerness/Curiosity }\end{array}$ & $6.18 \pm 1.42$ & $7.01 \pm 1.47$ & $-.83 \pm 2.06$ & -.3 .29 & $.002 * * *$ \\
\hline Self Confidence & $7.35 \pm 1.35$ & $7.47 \pm 1.25$ & $-.12 \pm 1.84$ & -.534 & .585 \\
\hline
\end{tabular}




\subsection{Difference of problem-solving ability after applying teaching method through google classroom}

After classes through Google Classroom, Problem clarification $(\mathrm{t}=-2.56, \mathrm{p}=.014)$, Information gathering $(\mathrm{t}=-2.16, \mathrm{p}=.015)$, Divergent thinking, Planning abilities $(\mathrm{t}=-2.17$, $\mathrm{p}=.035),(\mathrm{t}=-2.16, \mathrm{p}=.015)$ Planning abilities $(\mathrm{t}=-3.29, \mathrm{p}=.002)$, Assessment $(\mathrm{t}=-2.56, \mathrm{p}=.014)$ and Feedback ( $\mathrm{t}=-2.17, \mathrm{p}=.035)$ showed significant differences. There were no differences in Analysis skill ( $\mathrm{t}=.899, \mathrm{p}=.378)$, and Execution\& Risk-taking $(\mathrm{t}=.756 \mathrm{p}=.585)$ [Table 4].

Table 4. Difference of problem-solving ability after applying teaching method through google classroom $(\mathrm{N}=96)$

\begin{tabular}{|c|c|c|c|c|c|}
\hline Variables & $\begin{array}{l}\text { Pretest } \\
\mathrm{M} \pm \mathrm{SD}\end{array}$ & $\begin{array}{l}\text { Posttest } \\
M \pm S D\end{array}$ & $\begin{array}{c}\text { Paired Differences } \\
\mathrm{M} \pm \mathrm{SD}\end{array}$ & $\mathrm{t}$ & $\mathrm{p}$ \\
\hline $\begin{array}{c}\text { Problem } \\
\text { clarification }\end{array}$ & $14.31 \pm 2.65$ & $18.32 \pm 3.66$ & $-4.01 \pm 1.01$ & -.2 .56 & $.014 * *$ \\
\hline $\begin{array}{l}\text { Information } \\
\text { gathering }\end{array}$ & $16.05 \pm 2.50$ & $17.74 \pm 3.00$ & $-1.02 \pm 2.10$ & -2.16 & $.015 * *$ \\
\hline Analysis skill & $15.4 \pm 2.44$ & $15.66 \pm 3.59$ & $-.17 \pm 1.53$ & .888 & .378 \\
\hline Divergent thinking & $15.7 \pm 2.51$ & $16.8 \pm 3.13$ & $-.84 \pm 3.18$ & -2.17 & $.035 * *$ \\
\hline Decision making & $19.0 \pm 2.98$ & $19.0 \pm 2.9$ & $-.03 \pm 2.05$ & .905 & .465 \\
\hline Planning abilities & $15.3 \pm 3.22$ & $16.8 \pm 3.67$ & $-1.35 \pm 2.06$ & -.3 .29 & $.002 * * *$ \\
\hline $\begin{array}{c}\text { Execution\& risk- } \\
\text { taking }\end{array}$ & $15.5 \pm 3.17$ & $16.1 \pm 3.32$ & $-.12 \pm 1.84$ & .756 & .585 \\
\hline Assessment & $17.1 \pm 2.81$ & $18.9 \pm 3.31$ & $-1.82 \pm 2.60$ & -.2 .56 & $.014 * *$ \\
\hline Feedback & $16.4 \pm 3.46$ & $17.9 \pm 3.84$ & $-1.44 \pm 3.18$ & -2.17 & $.035 * *$ \\
\hline
\end{tabular}

3.5. Correlations among critical thinking, self-regulated learning ability, and academic major satisfaction after applying teaching method through google classroom

After classes through Google Classroom, the correlations among the variables were found. Critical thinking and Problem-Solving Ability ( $\mathrm{r}=352, \mathrm{p}=.002)$, critical thinking and SelfRegulated Learning Ability ( $\mathrm{r}=.370, \mathrm{p}=.003)$, Critical thinking and major satisfaction $(\mathrm{r}=.514$, $\mathrm{p}=.000$ ), Problem-Solving Ability and Self-Regulated Learning Ability ( $\mathrm{r}=.661, \mathrm{p}=.000)$, Problem-Solving Ability and major satisfaction $(r=.523, \mathrm{p}=.000)$, Self-Regulated Learning Ability and major satisfaction $(\mathrm{r}=.594, \mathrm{p}=.000)$ showed significant positive correlations [Table 5].

Table 5. Correlations among Critical Thinking, Problem-Solving Ability, Self-Regulate Learning Ability, and Academic Major Satisfaction after applying teaching method through Google Classroom $(\mathrm{N}=96)$

\begin{tabular}{|c|c|c|c|c|}
\hline Variables & Critical thinking & $\begin{array}{c}\text { Problem-Solving } \\
\text { Ability }\end{array}$ & $\begin{array}{c}\text { Self-Regulated } \\
\text { Learning Ability }\end{array}$ & Major satisfaction \\
\hline
\end{tabular}




\begin{tabular}{|c|c|c|c|c|}
\hline Critical thinking & 1 & - & - & - \\
\hline Problem-Solving Ability & $.352 * * *(.002)$ & 1 & - & - \\
\hline $\begin{array}{c}\text { Self-Regulated Learning } \\
\text { Ability }\end{array}$ & $.370 * * *(.003)$ & $.661 * * *(.000)$ & 1 & 1 \\
\hline $\begin{array}{c}\text { Academic Major } \\
\text { Satisfaction }\end{array}$ & $.514 * *(.000)$ & $.523 * * *(.000)$ & $.594 * * *(.000)$ & 1 \\
\hline
\end{tabular}

\section{Conclusion and suggestion}

This study was conducted to develop and evaluate the impact of education through Google Classroom on performance-based nursing education such as critical thinking, problem-solving ability, self-regulated learning ability, and academic major satisfaction with the face-to-face instructional closure due to COVID-19. The methodology used in this research is an experimental study of a group of pretest-posttest design, which was designed to check for differences before and after the intervention through Google Classroom to the treatment group.

The generalization of the results of this study is limited because they were targeted at students in the Department of Nursing at University. Therefore, it is suggested that its effectiveness should be verified through repeated studies to confirm its effectiveness.

Based on the results of this study, I would like to make the following suggestions.

First, in the domestic nursing class field, we propose a continuous repetitive study of intelligent checks on the effectiveness of classes made through non-face-to-face classes.

Second, it proposes a qualitative study related to the experiences of students and instructors in non-face-to-face classes such as Google Classroom.

Third, it is suggested to develop measurement tools for non-face-to-face classes such as Google Classroom.

\section{References}

[1] https://www.who.int/emergencies/diseases/novel-coronavirus-2019: WHO's March 11, “Covid-19 Pandemic Declaration," (2020)

[2] Korea Centers for Disease Control and Prevention, 2nd Basic Plan for Prevention and Management of Infectious Diseases, (2018)

[3] D. E. Lee, "Preparation for infectious diseases, abroad and Response Trends at home," Korea Health Industry Promotion Agency Expert, vol.1, pp1-31, (2017)

[4] K. O. Choi and Y. M. Park. "The effects of team-based learning on problem solving ability, critical thinking disposition and self-directed learning in undergraduate nursing students," Journal of East-West Nursing Research, vol.20, no.2, pp.154-159, (2014)

[5] Yoon J., "Development of an instrument for the measurement of critical thinking disposition in nursing," Ph.D. dissertation, Catholic University, Seoul, (2004)

[6] P. R. Pintrich and E. V. De Groot, "Motivational and self-regulated learning component of classroom academic performance," Journal of Educational Psychology, vol.8, no.2, pp33-40, (1990)

[7] Korea Educational Development Institute, "A study on the development of life capacity measurement tools: communication, problem solving focusing on ability, self-directed learning ability," RR 2003-15-03 (Basic Study), (2003)

[8] H. S. Park, J. M. Yun, S. N. Lee, S. R. Lee, and M. S. Lee, "The relationship between self-efficacy, major satisfaction and career decision level of nursing students," Journal of Health Information Station, vol.43, no.1, pp.35-45, (2018) 
The Effect of Classes through Google Classroom due to COVID-19 on Outcome-Based Nursing Education

[9] H. S. Park, J. M. Yun, S. N. Lee, S. R. Lee, and M. S. Lee, "The relationship between self-efficacy, major satisfaction and career decision level of nursing students," Journal of Health Information Station, vol.43, no.1, pp.35-45, (2018) 